Research, part of a Special Feature on Sustainable Land-Use Practices in Mountain Regions: Integrative Analysis of Ecosystem Dynamics Under Global Change, Social-Economic Impacts, and Policy Implications

\title{
Trade-Offs between Ecosystem Services in a Mountain Region
}

\author{
$\underline{\text { Simon Briner }}^{1}$, Robert Huber $^{2}$, Peter Bebi $^{3}$, Ché Elkin ${ }^{4}$, Dirk R. Schmatz $^{2}$ and Adrienne Grêt-Regamey ${ }^{5}$
}

\begin{abstract}
Mountain ecosystems provide a broad range of ecosystem services (ES). Trade-offs between different ES are an important aspect in the assessment of future sustainable land-use. Management of ES in mountain regions must confront the challenges of spatial and temporal heterogeneity, and interaction with structural changes in agriculture and forestry. Using a social-ecological modeling framework, we assess the relationships between forest and agricultural ES in a mountain region in Switzerland. Based on the concept of jointness in production, we evaluated trade-offs and synergies among food provision, biodiversity conservation, carbon sequestration, and protection against natural hazards. Results show that increasing the provision of a focal ES in a mountain region may result in alternating trade-offs and synergies, depending on the interaction of economic and technological interdependencies. Thus, management schemes aiming to increase the provision of one focal ES have to consider not only the technological or biological nature of interrelationships, but also the economic interdependencies among different ES. Trade-offs and synergies from these interactions strongly depend on the underlying structural and environmental conditions driven by socioeconomic and climatic developments.
\end{abstract}

Key Words: agriculture; climate change; ecosystem services; forestry; land-use change; model-based scenario analysis; mountainous regions; trade-offs

\section{INTRODUCTION}

Trade-off analysis is an important facet in assessment studies of ecosystem services (ES; Carpenter et al. 2009a, Seppelt et al. 2011), and it is a key issue when integrating ES in landscape planning, management, and decision making (de Groot et al. 2010) and in the analysis of alternative pathways that lead to future sustainable land use (Rounsevell et al. 2012). Tradeoffs between ES emerge in situations in which one service increases at the cost of another ES (Bennett et al. 2009, Raudsepp-Hearne et al. 2010). The reverse of trade-offs are synergies, which can be defined as situations in which both services either increase or decrease (Bennett et al. 2009, Haase et al. 2012).

Trade-offs and synergies between ES can result from common drivers impacting multiple ES and from interactions among ES (Bennett et al. 2009). Many studies have analyzed the effect of common drivers such as land-use and land-cover changes on ES trade-offs at different spatial scales and time scales (Foley et al. 2005, Steffan-Dewenter et al. 2007, Naidoo et al. 2008, Polasky et al. 2011, Haines-Young et al. 2012, Hall et al. 2012, Maes et al. 2012). The analysis of interactions among $\mathrm{ES}$, however, is less common because of the nonlinear behavior of the underlying interactions (Koch et al. 2009) and the complexity arising from different production processes in time and space (Baumgärtner 2000, Boisvert 2001). For example, a complementary relationship between food and biodiversity at low levels of production intensity may change to a competitive relationship at higher levels of intensity (Harvey 2003, Hodge 2008). In this context, the concept of jointness in production offers a helpful approach (Baumgärtner et al. 2001), especially with respect to interactions between provision services from agriculture and forestry and the provision of other ES (Wossink and Swinton 2007). Joint production implies that there are two different causes for interactions between ES: biological interdependencies and economic interdependencies (Abler 2004). The latter are of specific importance in managed landscapes where the provision of ES is strongly influenced by human activities.

In managed mountain ecosystems, which provide myriad ES, the complexity of interactions among ES is high (EEA 2010, Huber et al. 2013a), and sites that are either marginally or periodically productive may be more sensitive to climate and socioeconomic shifts (Schröter et al. 2005, Rounsevell et al. 2006). In particular, because of the heterogeneity of topography and other landscape characteristics, spatial dynamics are important (Bolliger et al. 2008). Furthermore, climate change may differentially influence the constituents of the ecosystem, e.g., the climatic response of grassland versus that of forest (Mooney et al. 2009, Power 2010). For agriculture, these spatial and temporal characteristics of mountain ecosystems have led to their small-scale agricultural structure, which is particularly recognizable in the European Alps (Flury et al. 2013). Managing trade-offs in the provision of mountain ES must therefore take into account the spatial

${ }^{1}$ ETH Zurich, Agri-Food and Agri-Environmental Economics Group, Department of Environmental Systems Science, ${ }^{2}$ Swiss Federal Institute for Forest, Snow and Landscape Research WSL, ${ }^{3}$ WSL Institute for Snow and Avalanche Research SLF, ${ }^{4}$ Forest Ecology, Department of Environmental Systems Science, ETH Zurich, ${ }^{5}$ Spatial and Landscape Development, Departement Civil, Environmental and Geomatic Engineering, ETH Zurich 
distribution of ES, how the trade-offs change over time, and how they interact with structural changes in agriculture and forestry.

Integrated modeling approaches allow for a spatially explicit quantification of the consequences of changes in land-use decisions on ES provision over time (Grêt-Regamey et al. 2012, Huber et al. 2013b). In addition, a spatially explicit integration of economic and environmental variables makes it possible to consider the effects of management and farm structural changes, such as shifts in the type of housed livestock that are kept, on ES provision. In recent years, a wide range of integrated modeling approaches has emerged to assess a variety of trade-offs in ES provision (Holman et al. 2005, Groot et al. 2007, Parra-López et al. 2008, Polasky et al. 2008, 2011, Nelson et al. 2009, Tallis and Polasky 2009, Chisholm 2010, Osgathorpe et al. 2011, Willemen et al. 2012).

Applying the existing integrative modeling framework ALUAM (Alpine Land Use Allocation Model; Briner et al. 2012), we present a scenario analysis to project spatially explicit trade-offs between food provision, protection against natural hazards, carbon sequestration, and biodiversity in a mountain region in the Swiss Alps. Our framework specifically allows for the considerations of the spatial scale at which decisions are made in mountainous regions. In addition to common drivers, ALUAM allows the economic interdependencies among ES to be considered. As is common in scenario analysis, this study does not provide information about what changes in ES provision can be expected in the future (Carpenter et al. 2006). However, it does outline the consequences of potential policy schemes that try to increase the provision of a single ES, i.e., the amount of money that needs to be invested to compensate farmers and the loss in the provision of other ES that has to be tolerated. We focus on the following research questions: (1) How are trade-offs and synergistic interactions among ES affected by climate and market changes? (2) How does the increase in the provision of a focal ES impact the provision of other ES?

\section{METHODS}

\section{Conceptual approach}

Our conceptual approach is presented in Figure 1. We evaluated a global change scenario that drives ES provision in a mountain region in the Swiss Alps. The main system components that determine ES provision in our agricultural and forest-dominated case study region are land use, farm structural changes, agricultural yields, and forest development. Changes in socioeconomic parameters such as prices and policies drive land-use changes, farm structural changes, and forest development. Climate changes, increases in temperature and changes in the precipitation pattern, influence agricultural yields and forest development.
Fig. 1. Drivers, system components, and interactions of ecosystem services (ES) provision in our modeling framework. Socioeconomic and climate change scenarios drive changes in our main system components, which directly affect ES provision. Biological and economic interdependencies have an indirect effect on the level of ES. Trade-offs and synergies in our modeling framework emerge from changes in common drivers and economic interactions among ES.

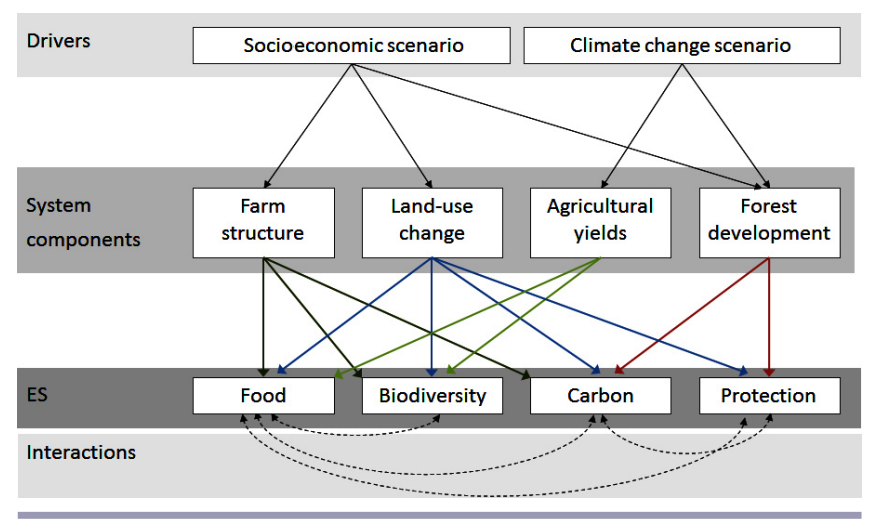

The changes in the underlying drivers represented in our scenario will affect the level of the spatially explicit provision of and the trade-offs among food, biodiversity, carbon sequestration, and protection against natural hazards, i.e., avalanche and rockfall protection, over time. In addition to these effects of drivers on trade-offs between ES, there are also interactions among the simulated ES. Because our case study region is a managed landscape, we use the concept of jointness in production to study the interactions between different ES. Jointness in economics refers to the fact that several outputs emerge together from a single production activity. There are three origins of jointness: technological or biological linkages, nonallocable inputs, and allocable fixed inputs (Lau 1972, Shumway et al. 1984, Leathers 1991). Abler (2004) summarized the last two factors as economic interdependencies in contrast to technological or biological interdependencies.

- Technical or biological linkages inherent in the production process refer to the fact that the agricultural and forest production processes can have inseparable effects on the environment. We use linear relationships to represent technological or biological interactions that are rooted in the ecosystem's structure and function. In other words, the effects of biological interactions between ES on the smallest decision unit (parcel or unit of livestock) are fixed. There are three examples of such interactions that are not altered in the modeling process. First, increased food production on one parcel in our 
spatially explicit modeling framework will reduce the biodiversity at this parcel level, and vice versa. Second, an increase in the number of animals housed in our simulation will automatically lead to an increase in greenhouse gas emissions. Accordingly, a decrease in the number of animals will decrease greenhouse gas emissions. Third, an increase in the protection from natural hazard through an increase in forest stands will inherently increase the sequestration of carbon emissions. Less protection is automatically associated with a decrease in the net sequestration of carbon.

- Nonallocable inputs imply that the outputs of two products depend on each other, e.g., using land to provide food typically also has an impact on the corresponding landscape's biodiversity and cultural services. The input factor land, however, cannot be allocated solely to either the production of food or to the provision of biodiversity or cultural services. Nonallocable inputs are at the heart of agricultural land-use optimization models (Buysse et al. 2007) and are represented in our integrated approach by considering ES integral production activities in our simulations. For example, suckler cows, which are kept on extensive grassland, provide food and maintain a valuable habitat at the same time. Thus, changes in production activities will change the inputs used and consequently will affect the provision of ES.

- Fixed inputs at a farm level lead to a competitive relationship between the production of marketable and nonmarketable ES. For example, if the amount of land belonging to a single farm is fixed, the allocation of a certain amount of land to biodiversity conservation will reduce the amount of land available for milk production. Fixed inputs are of increased importance in mountain regions because of their small-scale landscape structure and topographical barriers that do not allow for a full consideration of economies of scale in the production process. Fixed inputs are represented in our modeling framework by production restrictions at parcel, farm, and landscape levels that are rooted in the empirical realities of our case study region (Briner et al. 2012).

As a result of our conceptual approach, the trade-offs in our simulation framework are influenced in two ways. First, socioeconomic and climate changes directly drive the four system components in our simulation. As a consequence, ES provision also changes, leading to trade-offs and synergies at a landscape level because of common drivers in the two different simulation periods, 2010 and 2080. Second, biological and economic interdependencies indirectly affect ES provision. Whereas biological interdependencies between units of ES (per parcel or animal) are fixed in our modeling approach, economic interdependencies may change because of farm structural modifications. A sensitivity analysis, i.e., increasing the provision of one focal ES in our simulations, reveals the emerging trade-offs and synergies with the other ES represented in our modeling framework.

\section{Modeling framework}

We assessed trade-offs and synergies between different ES using the ALUAM modeling framework, which is an activitybased, spatially explicit land allocation model (Briner et al. 2012). To adequately simulate links between the provision of different ES, the ALUAM framework was expanded by adding the ability to calculate indices for the provision of biodiversity, protection, and carbon sequestration. We describe the model with respect to the main drivers of ES change in Figure 1. Climate change effects on forest development were simulated using the forest-landscape model LandClim. Climate change impacts on agricultural yields were calculated in a crop simulation model using regression analysis. Farm structural changes and land-use changes were simulated in an economic land-allocation model using an income maximization approach. See Appendix 1 for a graphic description of the data transfer. Table 1 illustrates all of the possible changes in drivers and interdependencies that lead to a change in ES provision.

\section{Forest development}

We used the process-based forest landscape model LandClim (Schumacher et al. 2004, Elkin et al. 2012) to simulate forest dynamics and to estimate potential wood production. LandClim is a spatially explicit model that was specifically developed to assess the importance of climatic effects, natural disturbances, and management on forest dynamics (Schumacher et al. 2004, 2006). The model simulates forest growth in $25 \mathrm{~m} \times 25 \mathrm{~m}$ cells, using simplified versions of tree recruitment, growth, and competition processes. Forest growth is determined by climatic parameters, soil properties and topography, large-scale disturbances, and land-use and forest management. Individual cells are linked by the spatially explicit processes of seed dispersal, landscape disturbances, and forest management. To evaluate potential timber production within each cell, we implemented a forest management regime whereby forest stands are evaluated every 20 years to determine if the stand should be entered and timber removed. The potential value of timber production on the specific cell is then passed to the economic land-use allocation model ALUAM.

\section{Crop yields}

Projected future yields of relevant crops were calculated using FAO data from the Food and Agriculture Organization of the United Nations (FAO) on optimal and absolute crop growing conditions (FAO 2007). Using minimum and maximum temperature, precipitation values, and values that define the crops' temperature and precipitation extremes, we fit a relative crop yield curve for temperature and precipitation values using an incomplete beta distribution. These species-specific crop 
Table 1. System components affected by scenarios, biological and economic interdependencies, and examples of activity changes that result in trade-offs and synergies between ecosystem services (ES) in Alpine Land Use Allocation Model (ALUAM).

\begin{tabular}{|c|c|c|c|}
\hline $\begin{array}{l}\text { Common system components } \\
\text { influenced by global change drivers }\end{array}$ & Type of interdependency & $\begin{array}{l}\text { Example of activity change leading } \\
\text { to trade-offs }\end{array}$ & $\begin{array}{l}\text { Example of activity change leading } \\
\text { to synergies }\end{array}$ \\
\hline \multicolumn{4}{|l|}{ Food $\leftrightarrow$ Biodiversity } \\
\hline Land-use changes & \multirow{3}{*}{$\begin{array}{l}\text { Biological interdependencies at a } \\
\text { parcel level; economic } \\
\text { interdependencies at a regional level }\end{array}$} & \multirow{3}{*}{$\begin{array}{l}\text { Substitution of extensively used } \\
\text { grassland }\end{array}$} & \multirow{3}{*}{$\begin{array}{l}\text { Changes in the spatial pattern of food } \\
\text { production resulting in the } \\
\text { intensification and extensification of } \\
\text { land use at the same time but at } \\
\text { different locations }\end{array}$} \\
\hline Farm structural changes & & & \\
\hline Agricultural yields & & & \\
\hline \multicolumn{4}{|l|}{ Food $\leftrightarrow$ Carbon sequestration } \\
\hline Farm structural changes & Biological interdependencies at a & Increase in livestock activities. & Substitution of livestock with crop \\
\hline Land-use changes & $\begin{array}{l}\text { parcel level and unit of livestock; } \\
\text { economic interdependencies at a } \\
\text { farm level }\end{array}$ & & production activities \\
\hline \multicolumn{4}{|c|}{ Food $\leftrightarrow$ Protection from gravitational hazard } \\
\hline Land-use changes & No interactions & Substitution of farmland with forest & $\begin{array}{l}\text { Climate changes induced an increase } \\
\text { in agricultural yields and forest } \\
\text { growth }\end{array}$ \\
\hline \multicolumn{4}{|l|}{ Biodiversity $\leftrightarrow$ Carbon sequestration } \\
\hline $\begin{array}{l}\text { Farm structural changes } \\
\text { Land-use changes }\end{array}$ & $\begin{array}{l}\text { Economic interdependencies at a } \\
\text { farm level }\end{array}$ & $\begin{array}{l}\text { Increase in the number of suckler } \\
\text { cows (increasing the potential for }\end{array}$ & $\begin{array}{l}\text { Reduction in livestock activities that } \\
\text { reduced high-quality roughage }\end{array}$ \\
\hline & & $\begin{array}{l}\text { extensively used grassland while also } \\
\text { increasing carbon emissions) }\end{array}$ & demand \\
\hline \multicolumn{4}{|c|}{ Biodiversity $\leftrightarrow$ Protection from gravitational hazard } \\
\hline Land-use changes & No interactions & $\begin{array}{l}\text { Increase in managed forest area on } \\
\text { extensively used grassland }\end{array}$ & No synergies possible in ALUAM \\
\hline \multicolumn{4}{|c|}{ Carbon $\leftrightarrow$ Protection from gravitational hazard } \\
\hline $\begin{array}{l}\text { Forest development } \\
\text { Land-use changes }\end{array}$ & $\begin{array}{l}\text { Biological interdependencies at a } \\
\text { parcel level }\end{array}$ & No trade-offs possible in ALUAM & $\begin{array}{l}\text { Increase in forest growth and } \\
\text { forested area }\end{array}$ \\
\hline
\end{tabular}

yield curves were then used to calculate the relative yield for six crops, based on monthly precipitation and temperature values for each landscape cell $(100 \mathrm{~m} \times 100 \mathrm{~m})$ in the case study landscape. The projected realized yield was taken as the minimum yield value from the temperature and precipitation responses. To fit the data to our case study region, the yields actually used in the model were calculated by standardizing the values against the observed yield of crops in 2000 (Landwirtschaftliche Beratungszentrale Lindau, 2000).

\section{Farm structural changes and land-use change}

ALUAM is an economic land-use optimization model that simulates decisions at different levels, parcel, farm, and regional, to maximize the aggregated income of farmers and foresters in the case study region. As a result, land-use activities and intensity as well as management of livestock activities under future scenarios can be simulated. At the parcel level, spatially explicit data were used to design 13 different land-use activities (see Appendix 1) and 35 livestock activities. The latter include the mainly roughage-based livestock activities that are already available in the case study region: keeping dairy cows, suckler cows, heifer sheep, and dairy sheep. For each activity, its contribution to the farmers' income was calculated. Thereby, both subsidies and revenues from the sale of agricultural products were included in the calculation. The model considered direct costs as well as structural costs caused by the different land-use and livestock activities. Parameters of all relevant prices, subsidies, and costs were exogenous and were driven by the scenario assumptions. Decisions about land-use and livestock activities were linked over three different balances that were integrated in the model as constraints.

1. A nutrient balance ensures that nutrients from livestock activities and artificial fertilizer do not exceed $110 \%$ of the nutrient demand for land-use activities.

2. A fodder balance ensures that there is enough roughage of adequate quality produced by the land-use activities to feed the animals kept in the case study region, which also guarantees that all roughage is either consumed or sold in a market.

3. A labor balance ensures that there is enough qualified labor available for the different activities, including all management tasks. If additional labor is needed, it is possible to hire a restricted amount of additional labor.

In combination with farm structural conditions, i.e., stable sizes, these three balances are the core elements of economic interdependencies among ES.

\section{Indicators for ecosystem services provision}

\section{Protection from gravitational hazards}

The ability of forests to provide protection from gravitational hazards depends on the location of the forest stand as well as on the tree species mixture, the structural profile, the rooting 
stability of live trees, and the regeneration potential of the forests. Frehner et al. (2005) developed guidelines for forest attributes that need to be maintained for the forests to provide a protective function. Based on these guidelines, we developed a metric that assesses the general protective value of forests, the Gravitational Protection Forest Index (GPFI). The GPFI simulated the ability of forests to provide protection from all gravitational hazards, taking into account the forests' tree species mixtures, structural profiles, rooting stability, and regeneration. For a detailed description of the GPFI, see Appendix 2. The potential GPFI was calculated for every parcel that is located either inside a rockfall protection zone or an avalanche protection zone. Because forests can only prevent avalanche releases at the very beginning of avalanches (for about the first $150 \mathrm{~m}$ after release), we assumed that forest stands only provide protection from avalanches if the forests are located inside of their starting zones (Bebi et al. 2009). This calculation of the potential GPFI was done by LandClim for the current state and the climate scenario. These spatially explicit data were transferred to ALUAM. In the optimization process, ALUAM aggregated the potential GPFI of all parcels used as forests or as fallow land to calculate the regional protection index.

\section{Biodiversity}

Some typologies do not consider biodiversity an ES in itself (MEA 2005, Costanza 2008); however, a direct relationship between the range of biodiversity in an ecosystem and the elements that allow an ecosystem to function has been suggested based on theoretical studies (Ives and Carpenter 2007) as well as on observations and experiments (Hooper et al. 2005). In particular, a higher level of biodiversity is often attributed with a higher stability of ecosystems because diverse ecosystems contain species with different traits that allow them to respond to changes in the environment (Pohl et al. 2009). We refer to the typologies of de Groot et al. (2002) and Costanza et al. (1997), which suggest that habitat functions or refugia can be categorized as ES because they provide a suitable living and reproduction habitat for wild plants and animals. Because the provision of these habitats increases the cost of the agricultural production process, we do not doublecount the cost of biodiversity conservation. In mountainous areas, biodiversity is generally highest in alpine dry meadows (Baumgärtner and Hartmann 2001), and slightly lower in extensively managed meadows and pastures (Zoller and Bischof 1980, Dullinger et al. 2003, Herzog et al. 2005). In ALUAM, we therefore used the share of extensively cultivated meadows and dry meadows as an index for biodiversity.

\section{Carbon sequestration/release}

To calculate the net greenhouse gas sequestration, both the amounts of greenhouse gas emitted by agriculture and the carbon sequestered by forests were calculated. In these calculations, only emissions inside the region were considered. We did not consider emissions caused by the fabrication of inputs for production, e.g., artificial fertilizer, machinery, and buildings, or the emissions caused by burning harvested wood. We accounted for all greenhouse gas (GHG) emissions of agricultural activities, including indirect $\mathrm{N}_{2} \mathrm{O}$ emissions associated with $\mathrm{N}$ losses. On-farm emissions were calculated using the Intergovernmental Panel on Climate Change (IPCC) 2000 and 2007 methodology. Because emission levels are climate- and management-specific, these methodologies were adapted to Swiss conditions. The methods used to calculate the various on-farm emissions are summarized in Appendix 1. The amount of greenhouse gases emitted is primarily dependent on the number of livestock housed in the region. Because the animals' diet was not subject to the optimization process, the model had no possibility of optimizing this diet to decrease emissions. Other mitigation measures, such as supplementing the diet of ruminants with fat, were not considered because they are either not yet ready for use or are too expensive (Briner et al. 2011). Land use also had an impact on greenhouse gas emissions because the number of tractor hours on extensively used grassland is lower compared to crop or intensive grassland production, and so $\mathrm{CO}_{2}$ emissions are lower as well. In addition, nitrogen throughput is lower on extensively used land, causing lower nitrous oxide emissions.

Carbon sequestration by forests was calculated as the amount of carbon immobilized each year in aboveground tree biomass. Although additional carbon could also be stored in soil organic carbon stock (Lal 2005), these processes were not considered in this study. The release of greenhouse gases was calculated during the optimization process as a function of the number of respective animals as well as of the land use. The calculation of the amount of carbon sequestered by forests was based on the spatially explicit data input provided by LandClim on potential tree growth.

\section{Food provision}

For the assessment of food production, a wheat-equivalent index was calculated that considered the different values of crops and grassland for human nutrition. This index considers the fact that grassland has a lower human nutritional value because grass first has to be converted into milk or meat by animals. Crops such as wheat can be digested by humans, so they have a higher value than grassland. For a detailed description of the index, see Briner et al. (2012). Food provision was calculated during the optimization process as a direct function of the number of animals and of land use. It was impacted by climate change through the spatially explicit yield data provided by the crop model that underlay the optimization process.

\section{Calculations of trade-offs}

Out of the whole set of land-use and livestock activities in the optimization process, the different constraints to the agricultural activities were applied to define feasible subsets 
that form a solution space. For land-use activities, these subsets were not only defined for the aggregated regional level, but also for each parcel in which technological and biological interdependencies are represented. Thus, this solution space also defines the potential trade-offs in our framework (Table 1). In the optimization procedure, a set of land-use and livestock activities was then selected that maximizes the income of farmers and foresters.

To calculate trade-offs, we performed (a) a scenario analysis that resulted in different trade-offs and synergies that depended on common economic and environmental drivers, and (b) a sensitivity analysis for each ES. In other words, we increased the amount of one of the ES by a stepwise adding of additional constraints. For each simulation, the aggregated effects on the focal ES as well as on the other three ES were calculated. These values were then compared to the levels obtained in a nonconstrained economic optimum of our simulation. The development of ES provision at a landscape level was interpreted as a trade-off if the provision of the additional ES developed in the opposite direction to the focal ES. It was interpreted as synergy if the provision of the additional ES developed in the same direction as the focal ES.

Trade-offs are either related to a direct change in the system's components or to the economic interdependencies among the ES simulated in our framework. The applied approach assumes that there is pressure on farmers and foresters to increase the provision of ES, e.g., by establishing according command and control measures. Farmers and foresters under these new constraints still have the goal of maximizing their income, i.e., they look for a strategy that will allow them to provide the additional ES at lowest cost.

\section{STUDY REGION}

We applied our conceptual and modeling framework to the central Valais, a continental inner-alpine mountain area in the south of Switzerland (Fig. 2). The study area includes the Saas Valley (Saas-Fee, Stalden), the region around Visp in the main valley, and the Baltschieder Valley, with a total of 15,346 inhabitants. The area is $443.3 \mathrm{~km}^{2}$. Unproductive land accounts for $62 \%$ of the area, $20 \%$ of the area is covered by forest land, and about $16 \%$ of the land is used for agriculture. Agricultural production is mainly focused on milk and meat. Agriculture and forest land use play an important role in the use of the region as a recreation area and as a habitat for plants and wildlife. For more details about the study region, see Huber et al. 2013b.

\section{SCENARIO}

We assumed changing climatic and socioeconomic parameters, as they can be expected for the year 2080, following IPCC scenario A1FI (IPCC 2007). This scenario, a worst-case scenario, assumes an increase in the global mean surface temperature of $4^{\circ} \mathrm{C}$. Observed daily climate data from regional weather stations were provided by MeteoSwiss (www.meteoswiss.admin.ch). These point data were interpolated into gridded climate maps with a resolution of $100 \mathrm{~m}$, using the DAYMET algorithm (Thornton et al. 1997) and a digital elevation model from Swisstopo (2005). Monthly climate data according to the A1FI scenario (2001 to 2100) and observed climate data (1900 to 2000) at a resolution of 10 angular minutes were obtained from the Climatic Research Unit (CRU) of the University of East Anglia, Norwich, United Kingdom (Mitchell et al. 2004). We then applied the change factor method to downscale the observed data and the output of the global climate model HadCM3 to $100 \mathrm{~m}$ (Mitchell and Jones 2005). We calculated difference anomalies relative to a baseline period of 1961 to 1990 for temperature and relative anomalies for precipitation. The anomalies were interpolated to $100 \mathrm{~m}$ and then were recombined with the DAYMET data of the same baseline period to obtain the fine-scaled A1FI and observed climate maps for all of the years from 1900 to 2100.

Fig. 2. Case study region, the central Valais

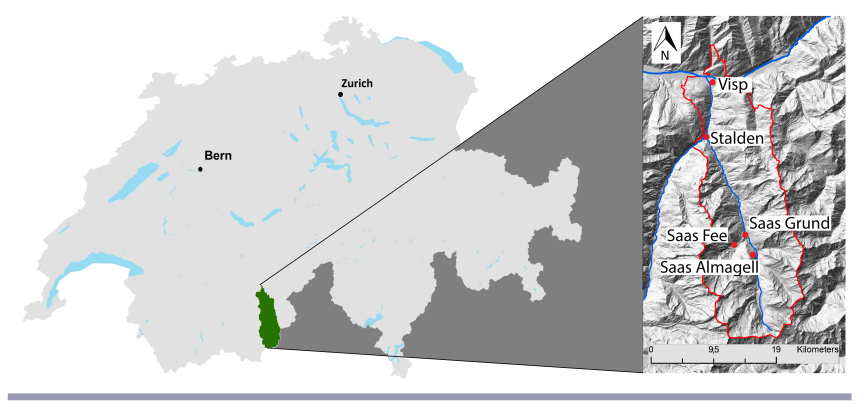

Policy and market scenarios were based on the same IPCC scenario. Abildtrup et al. (2006) used an expert survey and workshops to assess the relative impact of IPCC scenario A1FI on the prices of agricultural products and on production factors in the European Union (EU). The results of this study were used to calculate absolute parameters using current prices and costs in agricultural production in Switzerland as well as to calculate the gap in these parameters between Switzerland and the EU. These economic scenarios are described in more detail in Appendix 1 and by Briner et al. (2012).

\section{RESULTS}

\section{Trade-offs based on common drivers}

The impact of climate and economic changes in our simulations resulted in significant changes with respect to our main system components, i.e., farm structural changes, landuse changes including land-cover shifts, and changes in agricultural yields and forest development, in our case study region between 2010 and 2080. The three main effects in agriculture are (a) a reduction of cropland, (b) less-intensive grassland production, and (c) a shift from milk to meat 
production. In addition, a large part of the summer pastures are abandoned and become reforested. Climate change is projected to reduce timber production at low and intermediate elevations and to increase it at higher elevations, resulting overall in a net decrease in timber production. Overall, agricultural yields are projected to increase as a result of climate changes. With respect to ES provision, these common drivers resulted in a reduction of food provision, an increase in the biodiversity index, and a decrease in net carbon sequestration (for details, see Briner et al. 2012). In addition, at low and intermediate elevations, climate changes are projected to decrease the growth rate and increase the mortality of drought-intolerant tree species, such that the overall protection value of forests will be reduced in these areas (Bigler et al. 2006, Seidl et al. 2011). Thus, our common drivers are projected to lead to a trade-off between food provision and habitat services as well as (negative) synergies between food provision, net carbon sequestration, and the protection value of forests.

Based on these results, the following trade-offs and synergies emerge from interactions among ES if one focal ES is increased, as shown in figures 3 to 5 .

\section{Trade-offs based on interactions among ecosystem services}

\section{Increasing food provision}

Trade-offs between food production and other ES over time in our case study region are presented in Figure 3. Solid and dashed lines refer to changes under 2010 and 2080 conditions, respectively, and $100 \%$ refers to the level of food production in 2010. In our simulations, an increase in food provision up to $25 \%$ based on 2010 conditions resulted in a low trade-off with respect to carbon balance because an expansion of cropland increased food provision without additional emissions. A further increase would require an increasing milk production which, in turn, would decrease greenhouse gas sequestration by $13 \%$, compared to the level in 2010 . The impact of increased food provision on biodiversity in our simulations would result in a large trade-off. In particular, an increase in milk production would reduce the level of biodiversity because less intensively used grassland would be used more intensively to be able to produce an adequate amount of roughage. This increase would, however, not increase the farmers' income because less profitable activities would have to be chosen to meet the targeted level of food provision.

For 2080, the simulation results suggested a shift from cropland to grassland and a reduction of the overall production to $12 \%$ of the level in 2010. In addition, higher crop and grassland yields in 2080 would also allow for an expansion of food production to $155 \%$ whereas under 2010 conditions, the maximum increase in food production would be limited to $140 \%$. With a low level of agricultural output in 2080 , an increase of food production would be achieved by a substitution of grassland with crops on parcels suitable for arable farming. As a consequence, the number of livestock would also be reduced in this scenario and greenhouse gas emissions would decrease. Hence, there would be a synergetic effect between food provision and net carbon sequestration. In 2080, higher agricultural crop yields are assumed to allow for an extension of food production without additional livestock. An increase of food provision beyond $10 \%$ of the 2010 level, however, would again necessitate an increase in milk production, which would lead to a considerable increase in greenhouse gas emissions and thus to a trade-off between food and net carbon sequestration after this point. The level of biodiversity would decrease with increased food production. However, the reduction would be reversed if milk has to be produced to increase the level of food provision. Because the simulation in our crop model shows an increase in grassland yields, the same number of livestock can be fed using a smaller grassland area, which would allow for the upkeep of extensively used grassland in our simulations. Hence, we could observe a synergy between food production and biodiversity in 2080 beyond a production level of $110 \%$.

Fig. 3. Trade-offs between the provision of food and other ecosystem services (ES) as well as the sectoral income in 2010 (continuous lines) and in the year 2080 (dashed lines). Lines show the deviation of ES provision from the economic optimum in 2010 and 2080, respectively, if provision of food is increased over constraints. Food provision in 2010 equals $100 \%$. Because food provision in the economic optimum is lower in 2080 than in 2010, deviation already starts at $15 \%$.

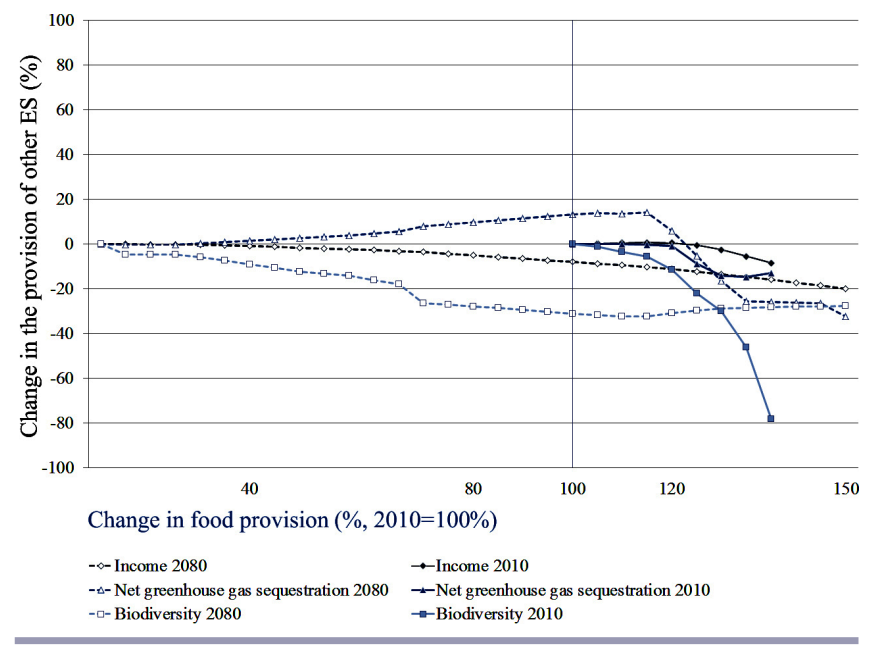

\section{Increasing biodiversity provision}

Trade-offs between the provision of habitat services, i.e., biodiversity and other ES estimated in our simulation, are presented in Figure 4. Food production would increase up to 
a simulated increase in the biodiversity index of $10 \%$. After this level, food production would decrease considerably, given 2010 conditions. The initial synergy between food production and biodiversity conservation can be explained by the additional use of land that was not cultivated in 2010. The use of this land as extensive grassland would increase both food and biodiversity provisions. This synergy is limited to a small amount of land. If biodiversity provision were further increased, a trade-off would emerge because an increase in the biodiversity index has to be accomplished by a switch from intensively used to extensively used grassland. This would restrict the amount of roughage and, consequently, the number in livestock as well. As a result, greenhouse gas emissions would decrease, which can be interpreted as a synergy between biodiversity provision and net carbon sequestration.

Fig. 4. Trade-offs and synergies caused by an increase in biodiversity provision in 2010 (continuous lines) and in 2080 (dashed lines). Lines show the deviation of ecosystem services (ES) provision from economic optimum in 2010 and in 2080, if provision of biodiversity is increased over constraints. Biodiversity provision in 2010 equals $100 \%$. Because biodiversity provision in the economic optimum is higher in 2080 than in 2010, deviation starts at 113\%.

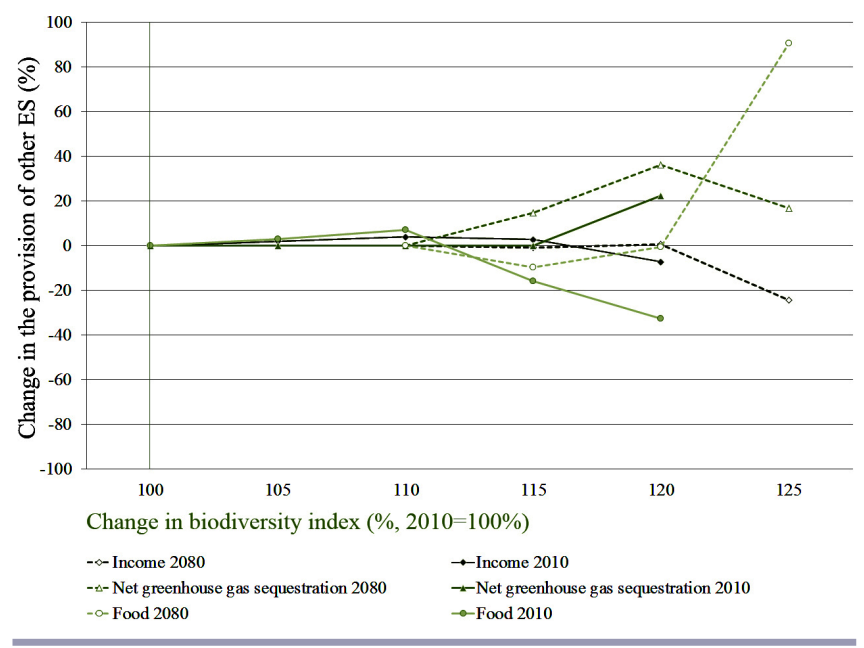

Under the 2080 scenario, our results estimated that food provision would slightly decrease and then increase by more than $80 \%$ if the biodiversity index were to exceed a level of $117 \%$ (Fig. 4). The reduction in food provision can be explained by a substitution of intensively and extensively used grassland, as was the case in 2010 . The increase after the $110 \%$ point is estimated as being caused by shifts in the production patterns from livestock to crop production, which allows for an extensification of grassland and an increase in food production at the same time. The synergy between biodiversity and food production beyond $120 \%$ in 2080 can be explained by the simulated expansion of the extensively used hay meadows on summer pastures, which would replace forested areas grown under our climate change scenario. This effect was also illustrated by the strong decrease in net greenhouse gas sequestration with an increasing biodiversity index beyond $120 \%$. Only a substantial increase in the biodiversity index would result in a trade-off with respect to the farmers' income because low-intensity grassland is remunerated with direct payments. The simulation results implied that in the 2010 and 2080 conditions, biodiversity could be expanded up to $120 \%$ (2010) and $125 \%$ (2080), of the level in 2010. Thus, compared to 2080 , farm structures in 2010 restrict farmers' ability to provide habitat services.

Fig. 5. Trade-offs and synergies caused by a change in the greenhouse gas balance in 2010 (continuous lines) and in 2080 (dashed lines). Lines show the deviation of ecosystem services (ES) provision from the economic optimum in 2010 and 2080, respectively, if greenhouse gas sequestration is increased over constraints. Greenhouse gas sequestration in 2010 equals $0 \%$. Because greenhouse gas sequestration in the economic optimum is lower in 2080 than in 2010, deviation starts at $-20 \%$.

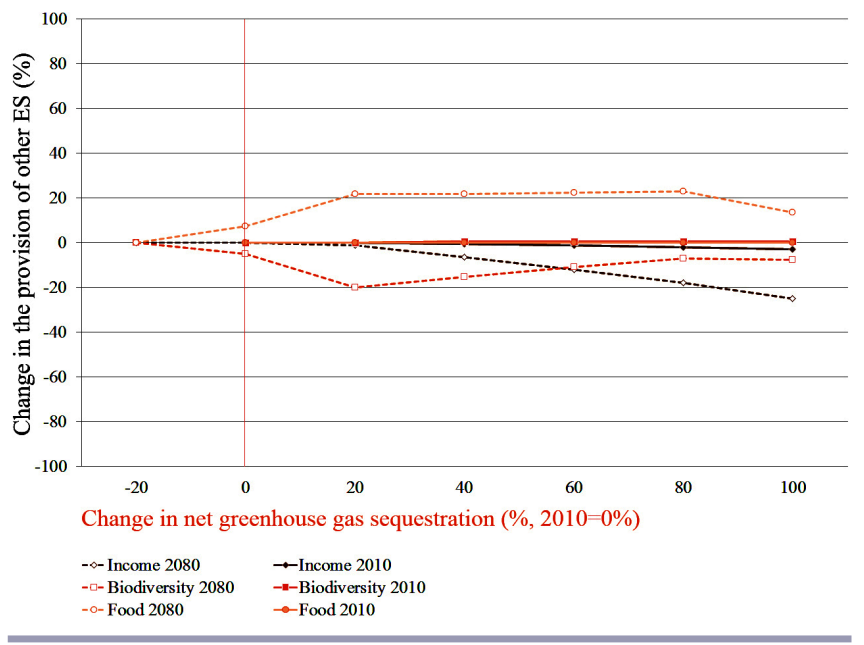

Increasing carbon sequestration

Figure 5 shows the changes in the provision of ES with increasing net greenhouse gas sequestration; $0 \%$ refers to the level of net greenhouse gas sequestration in 2010. Simulation results showed that by increasing the intensity of forest management and removing more trees, carbon sequestration could be increased. This increased sequestration in forests is assumed to compensate for an increase in greenhouse gas emissions caused by agriculture under 2010 conditions (solid lines). Because an intensification of forest management is relatively inexpensive, income only would decrease by about $4 \%$ if greenhouse gas balance were improved by $92 \%$; nearly the whole amount of greenhouse gases released by agriculture is sequestered by forests again. An additional improvement in 
the carbon balance could be achieved by reducing animal production. Because the decrease in food production caused by this measure would be compensated by an increase in crop production, it would not have a significant influence on food provision. Under the assumed scenario for 2080 (dashed lines), benefit from carbon sequestration in forests is, however, expected to decrease in the future, as climate changes will have a significant impact. If one wanted to compensate for the carbon sequestration decrease, the production system would have to be changed, in addition to changing forest management. Suckler cows, which represent the most profitable production activity, given the conditions in 2080, would be replaced by sheep, which emit less greenhouse gases per hectare. This shift would result in a decrease of biodiversity provision because slightly more grassland would be used. A further increase in greenhouse gas sequestration would lead to a replacement of sheep with dairy cows and an expansion of cropland. As a consequence, food production would remain at a constant level and biodiversity provision could be improved because of a re-extensification of grassland. However, levels of more than $80 \%$ would require a reduction in the number of livestock, which again would decrease food production in 2080 .

\section{Increasing protection against gravitational hazards}

In our simulations, there were only minor trade-offs and synergies in the protection from gravitational hazards that stemmed from interactions among ES. This can be explained by the fact that the calculation of the GPFI index only accounts for spatially explicit protection zones. Thus, even though there are significant land-cover changes when increasing a focal ES, these effects do not take place inside protection zones and thus do not influence the value of protection against gravitational hazards.

\section{DISCUSSION}

In a mountainous region, we simulated trade-offs and synergies between $E S$ that emerged from a continuous increase in one focal ES. To consider spatial and temporal drivers of ES provision, we applied our simulation framework for economic and environmental conditions in 2010 and 2080 in a spatially explicit manner. This approach allowed us to consider common (scenario-based) drivers and interactions in the analysis of trade-offs and synergies.

Whereas socioeconomic and climate changes are important drivers in the provision of mountain ES (Rodríguez et al. 2006, Carpenter et al. 2009a), the interactions among ES should also be considered in trade-off analysis (Bennett et al. 2009). We used the concept of jointness in production to include different types of interactions in our analysis. Jointness differentiates between biological and economic interdependencies as underlying mechanisms of interaction. Without the consideration of economic interdependencies, calculations of trade-offs or synergies based on land-use and land-cover changes may be overestimated or underestimated. Understanding the different causes of jointness is relevant in the assessment of trade-offs because the nature of the interactions also affects the outcome of policy schemes that try to manage these trade-offs (Wossink and Swinton 2007). For example, a decoupling from production subsidies to environmentally based payments in agriculture may have heterogeneous economic and ecological effects, depending on the farm type (Acs et al. 2010, Hanley et al. 2012) and the attitudes and preferences of farmers (Huber et al. 2013c).

With respect to the sensitivity analysis, our results imply that managing mountain ecosystems leads to trade-offs between the provision of marketable and nonmarketable ES. More food production, a marketable ES, reduces biodiversity and carbon sequestration. This fact has already been supported by other modeling studies in recent years across different ecosystems (Groot et al. 2007, Parra-López et al. 2008, Nelson et al. 2009, Polasky et al. 2011). The main factors that caused trade-offs in our simulation were biological interdependencies. More food provision for livestock necessitated the use of more intensive grassland. This automatically reduced the values of our indicators chosen to represent biodiversity and net carbon sequestration. In addition, generally, these trade-offs are also caused by fixed inputs at a farm level (Wossink and Swinton 2007). In contrast, nonallocable inputs may lead to alternating trade-offs or synergies with increasing levels of a focal ES, depending on the structural and environmental conditions (Huber and Lehmann 2010). An increase in the biodiversity index under 2010 conditions, for example, comes along with an increase in food provision, as long as the biodiversity increase remains small, and as long as nonallocable inputs, such as roughage, can be substituted. After a certain threshold, however, fixed inputs require land-use changes. Based on the technological interdependencies between land use and the provision of ES, a trade-off emerges.

The importance of taking into account such economic interdependencies along with common drivers of change is shown by the simulation results in 2080, which represent different economic and environmental conditions. Under these conditions, the interactions between economic and biological interdependencies were reversed. A small increase in the biodiversity index in this case led to a loss in food production because of fixed inputs. An increase of more than 25\% in biodiversity, however, resulted in an increase in extensively used grassland at the expense of forested area. The fodder balance in our simulation guaranteed that all of the additional biomass from this extensively used grassland was consumed by livestock. As a consequence, more livestock were necessary to consume the additional fodder, and food production emerged as a synergy of an increase in biodiversity. This effect was additionally supported by climate change impacts, which were supposed to increase grassland yields in our case study region. These complex interactions also led to different 
interactions between nonmarketable ES. In the simulations under 2080 conditions, we found a synergy between biodiversity and net carbon sequestration when the increase of the focalES was small. With higher levels of the biodiversity index, the increase in livestock reversed the relationship, and a trade-off emerged.

Our modeling framework did not permit us to simulate tradeoffs between the protective function of the forest and the carbon balance. Both ES would be improved if the forest area were to be expanded, and the level for both ES would decrease if the forest area were to be reduced. In addition, trade-offs are limited through Swiss forest laws that prohibit an active decrease of the current forest cover. Hence, trade-offs are currently limited to agricultural land, which potentially lowers the landscapes' potential level of reactivity to external drivers. To prevent resources from being wasted, this fact needs to be considered in managing ES provision because management schemes cannot influence land use on forest land (GrêtRegamey et al. 2012).

Two limitations have to be considered in the interpretation of our results. First, we applied rather coarse and simplified indicators for ES provision. For example, we assumed that forests have a lower biodiversity value than extensively used meadows (Dullinger et al. 2003). However, there are also forest types that provide a high value for biodiversity (Küffer and Senn-Irlet 2005, Spiecker 2003). In addition, recent work by Hanley et al. (2012) showed that extensification is not necessarily a suitable indicator for every aspect of biodiversity in grassland. In future work, the calculation of the biodiversity index should be improved to link the spatial location and biodiversity quality, e.g., via plant functional traits (Lavorel et al. 2010, Lavorel and Grigulis 2012). Second, the economic modeling framework considers a limited number of production systems. This is a general limitation of modeling studies because we cannot predict future technologies or production processes (Sterman 1991, Carpenter et al. 2009b). For example, new agroforestry systems could minimize the trade-off between food provision and the carbon balance (Briner et al. 2011); or biofuels from low-input, high-diversity grassland biomass (Tilman et al. 2006) may change the technological interdependence between provisioning and other ES from being trade-offs to being synergies. Future work on trade-offs using integrated modeling approaches should not only address the calculations of better indicators, but also should explicitly consider changes in the biological interdependencies between ES (Koch et al. 2009).

\section{CONCLUSION}

Our modeling study supports the claim for the joint consideration of socioeconomic and climate changes in an integrative framework when addressing global change impacts. Not only will climate changes affect the ability of ecosystems to provide certain ES, but socioeconomic and structural conditions will also influence land-use decision making and consequently the economic and technological relationship among different ES. Without an interlinked assessment of socioeconomic and climate changes, their impact on drivers of ES provision, and the underlying relationships among ES, the design of robust ecosystem management schemes would not be possible.

Primarily, our simulation results show two important aspects in the analysis of trade-offs and synergies in ES provision. First, increasing the provision of a focal ES in a mountain region may result in alternating trade-offs and synergies, depending on the interaction of economic and technological interdependencies. Thus, management schemes aiming to increase the provision of one focal ES have to consider not only the technological or biological nature of interrelationships, but also the economic interdependencies among different ES. Taking into account nonallocable and fixed inputs on different levels in the design of new management schemes may allow for small trade-offs or even synergies in the provision of multiple ES. Second, trade-offs and synergies from these interactions strongly depend on the underlying structural and environmental conditions driven by socioeconomic and climatic developments. Thus, our simulation results show the importance of considering the spatial heterogeneity of tradeoffs and synergies as well as economic and climate-changeinduced thresholds in the provision of marketable and nonmarketable ES. As a consequence, flexible forms of policy steering, policy measures adapted to local conditions, and the coordination of sectoral policies, e.g., through spatial planning, are important aspects of alternative policy schemes in mountain regions experiencing global change (Huber et al. 2013a).

Responses to this article can be read online at: http://www.ecologyandsociety.org/issues/responses. $\mathrm{php} / 5576$

\section{Acknowledgments:}

The study was financially supported by the Competence Centre Environment and Sustainability (CCES) of the ETH Domain (Swiss Federal Institutes of Technology Domain), Switzerland, as part of the research project MOUNTLAND. We are grateful to the Editor-in-Chief of Ecology and Society as well as the subject editor and two anonymous reviewers for their helpful comments on an earlier version of the manuscript.

\section{LITERATURE CITED}

Abildtrup, J., E. Audsley, M. Fekete-Farkas, C. Giupponi, M. Gylling, P. Rosato, and M. Rounsevell. 2006. Socio-economic scenario development for the assessment of climate change 
impacts on agricultural land use: a pairwise comparison approach. Environmental Science \& Policy 9:101-115.

Abler, D. 2004. Multifunctionality, agricultural policy, and environmental policy. Agriculture and Resource Economics Review 33:8-18.

Acs, S., N. Hanley, M. Dallimer, K. J. Gaston, P. Robertson, P. Wilson, and P. R. Armsworth. 2010. The effect of decoupling on marginal agricultural systems: implications for farm incomes, land use and upland ecology. Land Use Policy 27:550-563. http://dx.doi.org/10.1016/j.landusepol.2009.07.009

Baumgärtner, S. 2000. Ambivalent joint production and the natural environment: an economic and thermodynamic analysis. Physica-Verlag, Heidelberg, Germany.

Baumgärtner, S., H. Dyckhoff, M. Faber, J. Proop, and J. Schiller. 2001. The concept of joint production and ecological economics. Ecological Economics 36:365-372. http://dx.doi. org/10.1016/S0921-8009(00)00260-3

Baumgärtner, J., and J. Hartmann. 2001. The design and implementation of sustainable plant diversity conservation program for alpine meadows and pastures. Journal of Agricultural and Environmental Ethics 14:67-83. http://dx. doi.org/10.1023/A:1011345702135

Bebi, P., D. Kulakowski, and C. Rixen. 2009. Snow avalanche disturbances in forest ecosystems - state of research and implications for management. Forest Ecology and Management 257:1883-1892. http://dx.doi.org/10.1016/j. foreco.2009.01.050

Bennett, E. M., G. D. Peterson, and L. J. Gordon. 2009. Understanding relationships among multiple ecosystem services. Ecology Letters 12:1394-1404. http://dx.doi. org/10.1111/j.1461-0248.2009.01387.x

Bigler, C., O. U. Bräker, H. Bugmann, M. Dobbertin, and A. Rigling. 2006. Drought as an inciting mortality factor in Scots Pine stands of the Valais, Switzerland. Ecosystems 9:330-343. http://dx.doi.org/10.1007/s10021-005-0126-2

Boisvert, R. N. 2001. A note on the concept of jointness in production. Pages 105-123 in Organisation for Economic Cooperation and Development, editor. Multifunctionality: towards an analytical framework. Organisation for Economic Co-operation and Development, Paris, France.

Bolliger, J., F. Hagedorn, J. Leifeld, J. Böhl, S. Zimmermann, R. Soliva, and F. Kienast. 2008. Effects of land-use change on carbon stocks in Switzerland. Ecosystems 11:895-907. http:// dx.doi.org/10.1007/s10021-008-9168-6

Briner, S., C. Elkin, R. Huber, and A. Grêt-Regamey. 2012. Assessing the impacts of economic and climate changes on land-use in mountain regions: a spatial dynamic modeling approach. Agriculture, Ecosystems \& Environment 149:50-63. http://dx.doi.org/10.1016/j.agee.2011.12.011
Briner, S., M. Hartmann, R. Finger, and B. Lehmann. 2011. Greenhouse gas mitigation and offset options for suckler cow farms: an economic comparison for the Swiss case. Mitigation and Adaptation Strategies for Global Change 17:337-355. http://dx.doi.org/10.1007/s11027-011-9329-3

Buysse, J., G. Van Huylenbroeck, and L. Lauwers. 2007. Normative, positive and econometric mathematical programming as tools for incorporation of multifunctionality in agricultural policy modelling. Agriculture, Ecosystems \& Environment 120:70-81. http://dx.doi.org/10.1016/j.agee.2006.03.035

Carpenter S. R., E. M. Bennett, and G. D. Peterson. 2006. Scenarios for ecosystem services: an overview. Ecology and Society 11(1): 29. [online] URL: http://www.ecologyandsociety. org/vol11/iss1/art29

Carpenter, S. R., C. Folke, M. Scheffer, and F. Westley. $2009 b$. Resilience: accounting for the noncomputable. Ecology and Society 14(1): 13. [online] URL: http://www.ecologyandsociety. org/vol14/iss1/art13/

Carpenter, S. R., H. A. Mooney, J. Agard, D. Capistrano, R. S. Defries, S. Díaz, T. Dietz, A. K. Duraiappah, A. OtengYeboah, H. M. Pereira, C. Perrings, W. V. Reid, J. Sarukhan, R. J. Scholes, and A. Whyte. 2009a. Science for managing ecosystem services: beyond the Millennium Ecosystem Assessment. Proceedings of the National Academy of Sciences of the United States of America 106:1305-1312. http://dx.doi. org/10.1073/pnas.0808772106

Chisholm, R. A. 2010. Trade-offs between ecosystem services: water and carbon in a biodiversity hotspot. Ecological Economics 69:1973-1987. http://dx.doi.org/10.1016/ j.ecolecon.2010.05.013

Costanza, R. 2008. Ecosystem services: multiple classification systems are needed. Biological Conservation 141:350-352. http://dx.doi.org/10.1016/j.biocon.2007.12.020

Costanza, R., R. D'Arge, R. de Groot, S. Farber, M. Grasso, B. Hannon, K. Limburg, S. Naeem, R. V. O'Neill, J. Paruelo, R. G. Raskin, P. Sutton, and M. van den Belt. 1997. The value of the world's ecosystem services and natural capital. Nature 387:253-260. http://dx.doi.org/10.1038/387253a0

de Groot, R. S., R. Alkemade, L. Braat, L. Hein, and L. Willemen. 2010. Challenges in integrating the concept of ecosystem services and values in landscape planning, management and decision making. Ecological Complexity 7:260-272. http://dx.doi.org/10.1016/j.ecocom.2009.10.006

de Groot, R. S., M. A. Wilson, and R. M. J. Boumans. 2002. A typology for the classification, description and valuation of ecosystem functions, goods and services. Ecological Economics 41:393-408. http://dx.doi.org/10.1016/S0921-8009 (02)00089-7 
Dullinger, S., T. Dirnböck, J. Greimler, and G. Grabherr. 2003. A resampling approach for evaluating effects of pasture abandonment on subalpine plant species diversity. Journal of Vegetation Science 14:243-252. http://dx.doi.org/10.1111/ j.1654-1103.2003.tb02149.x

Elkin, C., B. Reineking, C. Bigler, and H. Bugmann. 2012. Do small-grain processes matter for landscape scale questions? Sensitivity of a forest landscape model to the formulation of tree growth rate. Landscape Ecology 27:697-711. http://dx.doi.org/10.1007/s10980-012-9718-3

European Environmental Agency (EEA). 2010. Europe's ecological backbone: recognising the true value of our mountains. European Environmental Agency, Copenhagen, Denmark.

Flury, C., R. Huber, and E. Tasser. 2013. Future of mountain agriculture in the Alps. Pages 105-126 in S. Mann, editor. The future of mountain agriculture. Springer Verlag, Berlin, Heidelberg, Germany. http://dx.doi.org/10.1007/978-3-642-33584-6 8

Foley, J. A., R. Defries, G. P. Asner, C. Barford, G. Bonan, S. R. Carpenter, F. S. Chapin, M. T. Coe, G. C. Daily, H. K. Gibbs, J. H. Helkowski, T. Holloway, E. A. Howard, C. J. Kucharik, C. Monfreda, J. A. Patz, I. C. Prentice, N. Ramankutty, and P. K. Snyder. 2005. Global consequences of land use. Science 309:570-574. http://dx.doi.org/10.1126/ $\underline{\text { science. } 1111772}$

Food and Agriculture Organization of the UN (FAO). 2007. Ecocrop: the crop environmental requirements database, the crop environmental response database. FAO, Rome, Italy.

Frehner, M., B. Wasser, and R. Schwitter. 2005. Nachhaltigkeit und Erfolgskontrolle im Schutzwald. Bundesamt für Umwelt, Wald und Landschaft (BUWAL), Bern, Switzerland.

Gazzarin, C., and G. Albisser Vögeli. 2010. ART-Bericht 733 Maschinenkosten 2010. Forschungsanstalt Agroscope Reckenholz-Tänikon ART, Ettenhausen, Switzerland.

Grêt-Regamey, A., S. H. Brunner, J. Altwegg, and P. Bebi. 2012. Facing uncertainty in ecosystem services-based resource management. Journal of Environmental Management. http://dx.doi.org/10.1016/j.jenvman.2012.07.028

Groot, J. C. J., W. H. Rossing, A. Jellema, D. J. Stobbelaar, H. Renting, and M. K. Van Ittersum. 2007. Exploring multiscale trade-offs between nature conservation, agricultural profits and landscape quality: a methodology to support discussions on land-use perspectives. Agriculture, Ecosystems \& Environment 120:58-69. http://dx.doi.org/10.1016/j. agee.2006.03.037

Haase, D., N. Schwarz, M. Strohbach, F. Kroll, and R. Seppelt. 2012. Synergies, trade-offs, and losses of ecosystem services in urban regions: an integrated multiscale framework applied to the Leipzig-Halle Region, Germany. Ecology and Society 17(3): 22. http://dx.doi.org/10.5751/ES-04853-170322

Haines-Young, R., M. Potschin, and F. Kienast. 2012. Indicators of ecosystem service potential at European scales: mapping marginal changes and trade-offs. Ecological Indicators 21:39-53. http://dx.doi.org/10.1016/j.ecolind.2011.09.004

Hall, J., T. Holt, A. Daniels, V. Balthazar, and E. Lambin. 2012. Trade-offs between tree cover, carbon storage and floristic biodiversity in reforesting landscapes. Landscape Ecology 27:1135-1147. http://dx.doi.org/10.1007/s10980-012-9755บ

Hanley, N., S. Acs, M. Dallimer, K. J. Gaston, A. Graves, J. Morris, and P. R. Armsworth. 2012. Farm-scale ecological and economic impacts of agricultural change in the uplands. Land Use Policy 29:587-597. http://dx.doi.org/10.1016/j. landusepol.2011.10.001

Harvey, D. R. 2003. Agri-environmental relationships and multifunctionality: further considerations. World Economy 26:705-725. http://dx.doi.org/10.1111/1467-9701.00543

Herzog, F., S. Dreier, G. Hofer, C. Marfurt, B. Schupbach, M. Spiess, and T. Walter. 2005. Effect of ecological compensation areas on floristic and breeding bird diversity in Swiss agricultural landscapes. Agriculture, Ecosystems and Environment 108:189-204. http://dx.doi.org/10.1016/j. agee.2005.02.003

Hodge, I. 2008. To what extent are environmental externalities a joint product of agriculture? Overview and policy implications. Pages 85-118 in Organisation for Economic Cooperation and Development, editor. Multifunctionality in agriculture: evaluating the degree of jointness, policy implications. Organisation for Economic Co-operation and Development, Paris, France. http://dx.doi.org/10.1787/9789264033627-en

Holman, I. P., M. D. A. Rounsevell, S. Shackley, P. A. Harrison, R. J. Nicholls, P. M. Berry, and E. Audsley. 2005. A regional, multi-sectoral and integrated assessment of the impacts of climate and socio-economic change in the UK. Climatic Change 71:9-41. http://dx.doi.org/10.1007/s10584-005-5927y

Hooper, D. U., F. S. Chapin III, J. J. Ewel, A. Hector, P. Inchausti, S. Lavorel, J. H. Lawton, D. M. Lodge, M. Loreau, S. Naeem, B. Schmid, H. Setälä, A. J. Symstad, J. Vandermeer, and D. A. Wardle. 2005. Effects of biodiversity on ecosystem functioning: a consensus of current knowledge and needs for future research. Ecological Monograph 75:3-35. http://dx.doi. org/10.1890/04-0922

Huber, R., S. Briner, A. Peringer, S. Lauber, R. Seidl, A. Widmer, F. Gillet, A. Buttler, Q. Bao Le, and C. Hirschi. 2013c. Modeling social-ecological feedback effects in the 
implementation of payments for environmental services in pasture-woodlands. Ecology and Society 18(2): 41. http://dx. doi.org/10.5751/ES-05487-180241

Huber, R., H. Bugmann, A. A. B. Buttler, and A. Rigling. 2013b. Sustainable land-use practices in European mountain regions under global change: an integrated research approach. Ecology and Society 18(3):37. http://dx.doi.org/10.5751/ ES-05375-180337

Huber, R., and B. Lehmann. 2010. Economies of scope in the agricultural provision of ecosystem services: An application to a high cost production region. German Journal of Agriculture Economics 2:91-105.

Huber, R., A. Rigling, P. Bebi, F. S. Brand, S. Briner, A. Buttler, C. Elkin, F. Gillet, A. Grêt-Regamey, C. Hirschi, H. Lischke, R. W. Scholz, R. Seidl, T. Spiegelberger, A. Walz, W. Zimmermann, and H. Bugmann. 2013a. Sustainable land use in mountain regions under global change: synthesis across scales and disciplines. Ecology and Society 18(3): 36. http:// dx.doi.org/10.5751/ES-05499-180336

Intergovernmental Panel on Climate Change (IPCC). 2000. Good practice guidance and uncertainty management in national greenhouse gas inventories. Intergovernmental Panel on Climate Change, Institute for Global Environmental Strategies, Tokyo, Japan.

Intergovernmental Panel on Climate Change (IPCC). 2007. Climate change 2007: the scientific basis. Contribution of Working Group I to the Fourth Assessment Report of the Intergovernmental Panel on Climate Change. Cambridge University Press, New York, USA. http://dx.doi.org/10.1017/ CBO9780511546013

Ives, A. R., and S. R. Carpenter. 2007. Stability and diversity of ecosystems. Science 317:58-62. http://dx.doi.org/10.1126/ science. 1133258

Koch, E. W., E. B. Barbier, B. R. Silliman, D. J. Reed, G. M. E. Perillo, S. D. Hacker, E. F. Granek, J. H. Primavera, N. Muthiga, S. Polasky, B. S. Halpern, C. J. Kennedy, C. V. Kappel, and E. Wolanski. 2009. Non-linearity in ecosystem services: temporal and spatial variability in coastal protection. Frontiers in Ecology and the Environment 7:29-37. http://dx. doi.org/10.1890/080126

Küffer, N., and B. Senn-Irlet. 2005. Influence of forest management on the species richness and composition of woodinhabiting basidiomycetes in Swiss forests. Biodiversity and Conservation 14:2419-2435. http://dx.doi.org/10.1007/ s10531-004-0151-Z

Lal, R. 2005. Forest soils and carbon sequestration. Forest Ecology and Management 220:242-258. http://dx.doi. org/10.1016/j.foreco.2005.08.015
Landwirtschaftliche Beratungszentrale Lindau (LBL). 2000. Deckungsbeitragskatalog 2000. Landwirtschaftliche Beratungszentrale Lindau, Eschikon, Zurich, Switzerland.

Lau, L. 1972. Profit functions of technologies with multiple inputs and outputs. Review of Economics and Statistics 54:281-289. http://dx.doi.org/10.2307/1937989

Lavorel, S., and K. Grigulis. 2012. How fundamental plant functional trait relationships scale-up to trade-offs and synergies in ecosystem services. Journal of Ecology 100:128-140. http://dx.doi.org/10.1111/j.1365-2745.2011.01914. $\underline{\mathrm{X}}$

Lavorel, S., K. Grigulis, P. Lamarque, M.-P. Colace, D. Garden, J. Girel, G. Pellet, and R. Douzet. 2010. Using plant functional traits to understand the landscape distribution of multiple ecosystem services. Journal of Ecology 99:135-147. http://dx.doi.org/10.1111/j.1365-2745.2010.01753.x

Leathers, H. D. 1991. Allocable fixed inputs as a cause of joint production: a cost function approach. American Journal of Agricultural Economics 73:1083-1090. http://dx.doi. org/10.2307/1242436

Maes, J., M. L Paracchini, G. Zulian, M. B. Dunbar, and R. Alkemade. 2012. Synergies and trade-offs between ecosystem service supply, biodiversity, and habitat conservation status in Europe. Biological Conservation 155:1-12. http://dx.doi. org/10.1016/j.biocon.2012.06.016

Millennium Ecosystem Assessment (MEA). 2005. Millennium Ecosystem Assessment, ecosystems and human well-being: synthesis. Island Press, Washington, D.C., USA.

Minonzio, G., A. Grub, and J. Fuhrer. 1998. MethanEmissionen der schweizerischen Landwirtschaft. Schriftenreihe Umwelt Nr. 298. Bundesamt für Umwelt, Wald und Landschaft (BUWAL), Bern, Switzerland.

Mitchell, T. D., T. R. Carter, P. Jones, and M. Hulme, 2004. A comprehensive set of climate scenarios for Europe and the globe. Tyndall Centre Working Paper 55. University of East Anglia, Norwich, UK.

Mitchell, T. D., and P. D. Jones. 2005. An improved method of constructing a database of monthly climate observations and associated high-resolution grids. International Journal of Climatology 25:693-712. http://dx.doi.org/10.1002/joc.1181

Mooney, H., A. Larigauderie, M. Cesario, T. Elmquist, O. Hoegh-Guldberg, S. Lavorel, G. M. Mace, M. Palmer, R. Scholes, and T. Yahara. 2009. Biodiversity, climate change, and ecosystem services. Current Opinion in Environmental Sustainability 1:46-54. http://dx.doi.org/10.1016/j.cosust.2009.07.006

Naidoo, R., A. Balmford, R. Costanza, B. Fisher, R. E. Green, B. Lehner, T. R. Malcolm, and T. H. Ricketts. 2008. Global mapping of ecosystem services and conservation priorities. 
Proceedings of the National Academy of Sciences 105:9495-9500. http://dx.doi.org/10.1073/pnas.0707823105

Nelson, E., G. Mendoza, J. Regetz, S. Polasky, H. Tallis, D. R. Cameron, K. M. A. Chan, G. C. Daily, J. Goldstein, P. M. Kareiva, E. Lonsdorf, R. Naidoo, T. H. Ricketts, and M. R. Shaw. 2009. Modeling multiple ecosystem services, biodiversity conservation, commodity production, and tradeoffs at landscape scales. Frontiers in Ecology and the Environment 7:4-11. http://dx.doi.org/10.1890/080023

Osgathorpe, L. M., K. Park, D. Goulson, S. Acs, and N. Hanley. 2011. The trade-off between agriculture and biodiversity in marginal areas: can crofting and bumblebee conservation be reconciled? Ecological Economics 70:1162-1169. http://dx.doi.org/10.1016/j.ecolecon.2011.01.010

Parra-López, C., J. C. J. Groot, C. Carmona-Torres, and W. H. Rossing. 2008. Integrating public demands into modelbased design for multifunctional agriculture: an application to intensive Dutch dairy landscapes. Ecological Economics 67:538-551. http://dx.doi.org/10.1016/j.ecolecon.2008.01.007

Pohl, M., D. Alig, C. Körner, and C. Rixen. 2009. Higher plant diversity enhances soil stability in disturbed alpine ecosystems. Plant Soil 324: 91-102. http://dx.doi. org/10.1007/s11104-009-9906-3

Polasky, S., E. Nelson, J. Camm, B. Csuti, P. Fackler, E. Lonsdorf, C. Montgomery, D. White, J. Arthur, B. GarberYonts, R. Haight, J. Kagan, A. Starfield, and C. Tobalske. 2008. Where to put things? Spatial land management to sustain biodiversity and economic returns. Biological Conservation 141:1505-1524. http://dx.doi.org/10.1016/j.biocon.2008.03.022

Polasky, S., E. Nelson, D. Pennington, and L. Johnson. 2011. The impact of land-use change on ecosystem services, biodiversity and returns to landowners: a case study in the state of Minnesota. Environmental and Resource Economics 48:219-242. http://dx.doi.org/10.1007/s10640-010-9407-0

Power, A. G. 2010. Ecosystem services and agriculture: tradeoffs and synergies. Philosophical Transactions of the Royal Society B 365:2959-2971. http://dx.doi.org/10.1098/ rstb.2010.0143

Raudsepp-Hearne, C., G. D. Peterson, and E. M. Bennett. 2010. Ecosystem service bundles for analyzing tradeoffs in diverse landscapes. Proceedings of the National Academy of Sciences 107:5242-5247. http://dx.doi.org/10.1073/pnas.0907284107

Rodríguez, J. P., T. D. Beard, Jr., E. M. Bennett, G. S. Cumming, S. Cork, J. Agard, A. P. Dobson, and G. D. Peterson. 2006. Trade-offs across space, time, and ecosystem services. Ecology and Society 11(1): 28. [online] URL: http://www. ecologyandsociety.org/vol11/iss1/art28/

Rounsevell, M. D. A., P. M. Berry, and P. A. Harrison. 2006. Future environmental change impacts on rural land use and biodiversity: a synthesis of the ACCELERATES project. Environmental Science \& Policy 9:93-100. http://dx.doi. org/10.1016/j.envsci.2005.11.001

Rounsevell, M. D. A., B. Pedroli, K.-H. Erb, M. Gramberger, A. Gravsholt Busck, H. Haberl, S. Kristensen, T. Kuemmerle, S. Lavorel, M. Lindner, H. Lotze-Campen, M. J. Metzger, D. Murray-Rust, A. Popp, M. Pérez-Soba, A. Reenberg, A. Vadineanu, P. H. Verburg, and B. Wolfslehner. 2012. Challenges for land system science. Land Use Policy 29:899-910. http://dx.doi.org/10.1016/j.landusepol.2012.01.007

Schmid, M., A. Neftel, and J. Fuhrer. 2000. Lachgasemissionen aus der Schweizer Landwirtschaft. Schriftenreihe der FAL 33. Eidgenössische Forschungsanstalt für Agrarökologie und Landbau, FAL Reckenholz, Zurich, Switzerland.

Schmid, M., A. Neftel, M. Riedo, and J. Fuhrer. 2001. Processbased modelling of nitrous oxide emissions from different nitrogen sources in mown grassland. Nutrient Cycling in Agroecosystems 60:177-187. http://dx.doi.org/10.1023/ A:1012694218748

Schröter, D., W. Cramer, R. Leemans, I. C. Prentice, M. B. Araújo, N. W. Arnell, A. Bondeau, H. Bugmann, T. R. Carter, C. A. Gracia, A. C. de la Vega-Leinert, M. Erhard, F. Ewert, M. Glendining, J. I. House, S. Kankaanpää, R. J. T. Klein, S. Lavorel, M. Lindner, M. J. Metzger, J. Meyer, T. D. Mitchell, I. Reginster, M. Rounsevell, S. Sabaté, S. Sitch, B. Smith, J. Smith, P. Smith, M. T. Sykes, K. Thonicke, W. Thuiller, G. Tuck, S. Zaehle, and B. Zierl. 2005. Ecosystem service supply and vulnerability to global change in Europe. Science 310:1333-1337. http://dx.doi.org/10.1126/science.1115233

Schumacher, S., H. Bugmann, and D. J. Mladenoff. 2004. Improving the formulation of tree growth and succession in a spatially explicit landscape model. Ecological Modeling 180:175-194. http://dx.doi.org/10.1016/j.ecolmodel.2003.12.055

Schumacher, S., B. Reineking, J. Sibold, and H. Bugmann. 2006. Modeling the impact of climate and vegetation on fire regimes in mountain landscapes. Landscape Ecology 21:539-554. http://dx.doi.org/10.1007/s10980-005-2165-7

Seidl, R., P. M. Fernandes, T. F. Fonseca, F. Gillet, A. M. Jönsson, K. Merganicová S. Netherer, A. Arpaci, J.-D. Bontemps, H. Bugmann, J. R. González-Olabarria, P. Lasch, C. Meredieu, F. Moreira, M.-J. Schelhaas, F. Mohren. 2011. Modelling natural disturbances in forest ecosystems: a review. Ecological Modelling 222:903-924. http://dx.doi.org/10.1016/ j.ecolmodel.2010.09.040

Seppelt, R., C. F. Dormann, F. V. Eppink, S. Lautenbach, and S. Schmidt. 2011. A quantitative review of ecosystem service studies: approaches, shortcomings and the road ahead. Journal of Applied Ecology 48:630-636. http://dx.doi.org/10.1111/ j.1365-2664.2010.01952.x 
Shumway, R. C., R. D. Pope, and E. K. Nash. 1984. Allocatable fixed inputs and jointness in agricultural production: implications for economic modeling. American Journal of Agricultural Economics 66:72-78. http://dx.doi.org/10.2307/1240617

Spiecker, H. 2003. Silvicultural management in maintaining biodiversity and resistance of forests in Europe-temperate zone. Journal of Environmental Management 67:55-65. http:// dx.doi.org/10.1016/S0301-4797(02)00188-3

Steffan-Dewenter, I., M. Kessler, J. Barkmann, M. M. Bos, D. Buchori, S. Erasmi, H. Faust, G. Gerold, K. Glenk, S. R. Gradstein, E. Guhardja, M. Harteveld, D. Hertel, P. Höhn, M. Kappas, S. Köhler, C. Leuschner, M. Maertens, R. Marggraf, S. Migge-Kleian, J. Mogea, R. Pitopang, M. Schaefer, S. Schwarze, S. G. Sporn, A. Steingrebe, S. S. Tjitrosoedirdjo, S. Tjitrosoemito, A. Twele, R. Weber, L. Woltmann, M.Zeller, and T. Tscharntke. 2007. Tradeoffs between income, biodiversity, and ecosystem functioning during tropical rainforest conversion and agroforestry intensification. Proceedings of the National Academy of Sciences 104:4973-4978. http://dx.doi.org/10.1073/pnas.0608409104

Sterman, J. D. 1991. A skeptic's guide to computer models. Pages 209-229 in G. O. Barney, G. W. B. Kreutzer, and M. J. Garrett, editors. Managing a nation: the microcomputer software catalog. Westview Press, Boulder, Colorado, USA.

Swisstopo. 2004. The digital height model of Switzerland DHM25. Federal Office of Topography, Bern, Switzerland.

Tallis, H., and S. Polasky. 2009. Mapping and valuing ecosystem services as an approach for conservation and natural-resource management. Annals of the New York Academy of Sciences 1162:265-283. http://dx.doi.org/10.1111/ j.1749-6632.2009.04152.x

Thornton, P. E., S. W. Running, and M. A. White. 1997. Generating surfaces of daily meteorological variables over large regions of complex terrain. Journal of Hydrology 190:214-251. http://dx.doi.org/10.1016/S0022-1694(96)03128-9

Tilman, D., J. Hill, and C. Lehman. 2006. Carbon-negative biofuels from low-input high-diversity grassland biomass. Science 314:1598-1600. http://dx.doi.org/10.1126/science.1133306

Willemen, L., A. Veldkamp, P. H. Verburg, L. Hein, and R. Leemans. 2012. A multi-scale modelling approach for analysing landscape service dynamics. Journal of Environmental Management 100:86-95. http://dx.doi. org/10.1016/j.jenvman.2012.01.022

Wossink, A., and S. M. Swinton. 2007. Jointness in production and farmers' willingness to supply non-marketed ecosystem services. Ecological Economics 64:297-304. http://dx.doi. org/10.1016/j.ecolecon.2007.07.003
Zoller, H., and N. Bischof. 1980. Stufen der Kulturintensität und ihr Einfluss auf Artenzahl und Artengefüge der Vegetation. Phytocoenologia 7:35-51. 


\section{Appendix 1. Characteristics of ALUAM}

\section{Interaction of submodels}

Fig. A1.1. Interaction between the different submodels in the Alpine Land Use Allocation Model

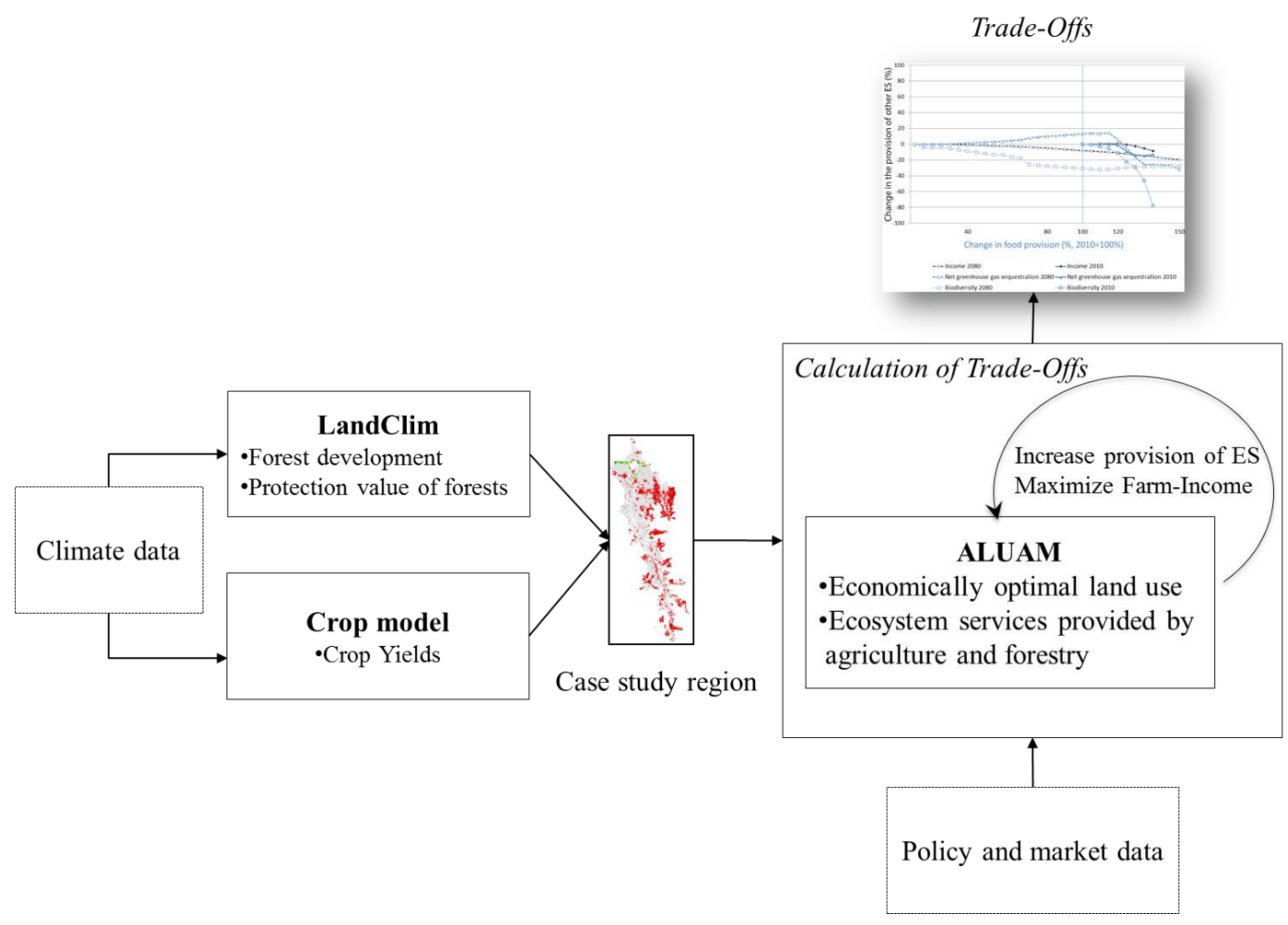

The assessment of changes in land-use and EGS is accomplished in two steps (Fig.1). In step one, the direct impacts of climate change on forest development and crop yields are calculated for each year between 2010 and 2080. This step involves amalgamating three data sources: (1) Within each simulated parcel $(100 \mathrm{~m} \mathrm{x} 100 \mathrm{~m})$ the potential yield of all agricultural and forestry activities (for an overview see Table 2) is simulated by the forestsimulation model LandClim and the crop yield model. (2) Spatially explicit data are calculated for each parcel. A digital elevation model is used to calculate elevation and slope of each parcel. Swiss Land Cover Statistics are used to determine which parcels are suitable for cultivation and a soil utility map is used to rate the different parcels according to their suitability for the land-use activities. Swiss Land Cover Statistics was used to calculate the distance of all parcels to the next farm. (3) Administrative data, e.g. the production zone the parcel is lying in, are assigned to the parcels. In step two, these spatially explicit yield estimates are combined

with policy and market scenarios in the economic model Alpine Land Use Allocation Model (ALUAM). ALUAM then simulates land-use decisions based on a profit maximizing approach. The results show both where land-use change occurs and what the combined impact of climate and economic change is. The data assigned to each parcel is thus combined with sources linking spatially explicit data with production parameters such as labor demand, nutrient demand, fodder production and the transport costs dependent on the distance between parcel and farmyard (Briner et al. 2012).

\section{Reference}

Briner, S., C. Elkin, R. Huber, and A. GrêtRegamey. 2012. Assessing the impacts of economic and climate changes on land-use in mountain regions: a spatial dynamic modeling approach. Agriculture, Ecosystems \& Environment 149:50-63. http://dx.doi.org/10.1016/j.agee.2011.12.011 
Land use activities in the Alpine Land Use Allocation Model (ALUAM)

Table A1.1. Land use activities as implemented in the ALUAM model

\begin{tabular}{lccc}
\hline \hline & intensive & $\begin{array}{c}\text { Intensity } \\
\text { mid-intensive }\end{array}$ & extensive \\
\hline Hay meadow & $\mathrm{X}$ & $\mathrm{X}$ & $\mathrm{X}$ \\
Grazed pasture & $\mathrm{x}$ & $\mathrm{x}$ & \\
Wheat & & $\mathrm{x}$ & \\
Barley & & $\mathrm{x}$ & \\
Potato & & $\mathrm{x}$ & \\
Sugar beet & $\mathrm{x}$ & Maintenance without \\
Maize & Maintenance incl. wood & & wood harvest \\
Forest & harvest & - & \\
Fallow & & - & \\
\hline
\end{tabular}

\section{Calculation of GHG emissions}

Table A1.2. References of methods applied in ALUAM to calculate on-farm greenhouse gas (GHG) emissions

\begin{tabular}{llll}
\hline \hline $\mathrm{GHG}$ & Emission Source & Influencing factor & Reference \\
\hline $\mathrm{CH}_{4}$ & Enteric fermentation & $\begin{array}{l}\text { Number of animals, Animal-specific methane } \\
\text { rate, feed mix, lipid supplementation }\end{array}$ & $\begin{array}{l}\text { IPCC 2000, Minonzio et } \\
\text { al. 1998 }\end{array}$ \\
& Manure & $\begin{array}{l}\text { Amount of different manures, feed mix, housing } \\
\text { system, pasture management }\end{array}$ & \\
$\mathrm{N}_{2} \mathrm{O}$ & Manure & $\begin{array}{l}\text { Amount of different types of manure, manure } \\
\text { management }\end{array}$ & IPCC 2000, \\
& Land-use & Fertilizer & Schmid et al. 2000, 2001 \\
& Indirect emission & Loss of N in different compounds & Schmid et al. 2000 \\
$\mathrm{CO}_{2}$ & Tractor/Machinery & Land-use intensity & Gazzarin and Albisser \\
& & & Vögeli 2010 \\
\hline
\end{tabular}

\section{References}

Minonzio, G., A. Grub, and J. Fuhrer. 1998. Methan-Emissionen der schweizerischen Landwirtschaft. Schriftenreihe Umwelt Nr. 298. Bundesamt für Umwelt, Wald und Landschaft (BUWAL), Bern.

IPCC, 2000. Emissions Scenarios - Summary for Policymakers. A Special Report of IPCC Working Group III, Intergovernmental Panel on Climate Change.

Schmid, M., Neftel, A., Fuhrer, J., 2000. Lachgasemissionen aus der Schweizer Landwirtschaft. Schriftenreihe der FAL 33. Eidgenössische Forschungsanstalt für Agrarökologie und Landbau, FAL Reckenholz, Zürich.
Schmid, M., Neftel, A., Riedo, M., Fuhrer, J., 2001. Process-based modelling of nitrous oxide emissions from different nitrogen sources in mown grassland. Nutrient Cycling in Agroecosystems 60: 177-187.

Gazzarin, C., Albisser Vögeli, G., 2010. ARTBericht-Maschinenkosten 2009/2010. Agroscope Reckenholz Tänikon, Ettenhausen. 


\section{Scenario assumptions}

Table A1.3. Economic scenarios applied in ALUAM (based on Briner et al. 2012)

\begin{tabular}{llccc}
\hline \hline & Unit & EU 2005 & 2010 & A1FI 2080 \\
\hline Milk & $\mathrm{CHF} / \mathrm{kg}$ & 0.46 & 0.75 & 0.24 \\
Beef & $\mathrm{CHF} / \mathrm{kg} \mathrm{CW}$ & 4.7 & 8.1 & 3.9 \\
Lamb & $\mathrm{CHF} / \mathrm{kg} \mathrm{CW}$ & 5.5 & 9.7 & 4.6 \\
Wheat & $\mathrm{CHF} / \mathrm{t}$ & 151 & 503 & 51 \\
Potato & $\mathrm{CHF} / \mathrm{t}$ & 149 & 407 & 76 \\
Sugar beet & $\mathrm{CHF} / \mathrm{t}$ & 61 & 64 & 16 \\
Barley & $\mathrm{CHF} / \mathrm{t}$ & 149 & 377 & 50 \\
Rapeseed & $\mathrm{CHF} / \mathrm{t}$ & 301 & 760 & 81 \\
Corn & $\mathrm{CHF} / \mathrm{t}$ & 174 & 379 & 113 \\
Pesticides & $\%$ & & 100 & 51 \\
Machinery $^{3}$ & $\%$ & & 100 & 52 \\
Fuel $^{3}$ & $\%$ & & 100 & 62 \\
Seed $^{3}$ & $\%$ & & 100 & 179 \\
Concentrate feed $^{2}$ & $\%$ & & 100 & 34 \\
\hline CHF: Swss & $\%$ & & &
\end{tabular}

CHF: Swiss francs; t: tons ; CW: Carcass weight

${ }^{1} \mathrm{EU}$ prices in 2005 were the base for the calculation of the prices in the future scenarios (Source: FOAG 2006).

${ }^{2}$ It was assumed that prices for concentrate feed behave as prices for cereals.

${ }^{3}$ Parameter derived directly from Abildtrup et al (2006)

\section{References}

Briner, S., C. Elkin, R. Huber, and A. GrêtRegamey. 2012. Assessing the impacts of economic and climate changes on land-use in mountain regions: a spatial dynamic modeling approach. Agriculture, Ecosystems \& Environment 149:50-63. http://dx.doi.org/10.1016/j.agee.2011.12.011
Abildtrup, J., E. Audsley, M. Fekete-Farkas, C. Giupponi, M. Gylling, P. Rosato, and M. Rounsevell. 2006. Socio-economic scenario development for the assessment of climate change impacts on agricultural land use: a pairwise comparison approach. Environmental Science \& Policy 9:101-115. 


\section{Appendix 2}

\section{Calculation of the General Forest Protection Index (GFPI)}

The GFPI simulates the ability of forests to provide protection against all gravitational hazards considering tree species mixture, structural profile of the forests, rooting stability and regeneration potential. Based on the guidelines developed by Frehner et al. (2005) the GFPI was calculated as follows:

$$
G P F I=\frac{50 * \alpha_{1}+25 * \alpha_{2}+15 * \alpha_{3}+10 * \alpha_{4}}{100}
$$

where,

$$
\begin{aligned}
& \alpha_{1}=\min \left[\left(\frac{\# \text { trees } / \text { ha } \text { with } D B H>24}{400}\right), 1\right] \\
& \alpha_{2}=\min \left[\left(\frac{\# \text { cohorts with trees }>24 \mathrm{~cm} \mathrm{DBH}}{4}\right), 1\right]
\end{aligned}
$$

$$
\alpha_{3}=\min \left[\left(\frac{\# \text { species }}{3}\right), 1\right]
$$

$$
\alpha_{4}=\min \left[\left(\frac{\# \text { cohorts with trees }<12 \mathrm{~cm} \mathrm{DBH}}{2}\right), 1\right]
$$

The weighting that was given to each attribute in equation A2.1 is based on an amalgamation of the forest protection evaluation that Frehner et al. (2005) did. It is structured such that a high number of stems is strongly favored. This reflects the impact of stem number on all the gravitational protection types. Additionally it reflects the view that achieving a forest structure that protects against gravitational hazards should be principle importance, while maintaining a mixed forest and a high level of regeneration potential is of secondary importance. The index ranges from 0 to 1 with 1 providing the maximum protection from gravitational hazards.

\section{Reference}

Frehner M., Wasser B., and Schwitter R. 2005. Nachhaltigkeit und Erfolgskontrolle im Schutzwald. Wegleitung für Pflegemassnahmen in Wäldern mit Schutzfunktion. Bundesamt für Umwelt, BAFU, Bern. S. 564. 